\title{
Increase and Decrease in Milk Production is affected by Pasture intake
}

\author{
Ian Aine Lepo \\ University of Diponegoro Faculty of Animal Agricultural Sciences Complex Dry. Someone Koesoemowardojo \\ Tembalang Semarang city, Central Java Province, Indonesia
}

\begin{abstract}
Quality pasture reduces input costs and increases net returns, increases yield and quality of forage, decreases purchased feed, decreases equipment and fuel, decreases manure handling and bedding, better animal health and, reduces labor to feed or harvest the forage. Successes at maintaining good milk yield are generally due to an ability to optimize pasture yield and quality; supplement rations to meet energy requirements; and balance diets for undegradable protein in livestock rearing.

Yields of high quality pasture forage can be similar to yields obtained on most farms that mechanically harvest forage for hay or silage. Quality pastures can achieve 4- 6 ton of dry matter per acre and can be grazed 6-9 times each season in the temperate and all year round in the tropical countries.An experiment was conducted to determine the Total Non-structural carbohydrates (TNC) of three napier grass (Pennisetumpurpurem) harvested at vegetative and reproductive phases. The cultivars tested were Taiwan (Gt), King (Gk), and Mott (Gm) and arranged in a $3 \times 2$ of treatments with four replicates following nested designed.

The results showed that the highest sugar content $(P<0.01)$ was found in Gt cultivar and the lowest was in Gm cultivar. The highest starch content $(P<0.01)$ was found in in Gk cultivar and the lowest was in Gt cultivar. TNC content of Gt and Gk cultivars were not significantly different, but both were not significantly higher $(P<0.01)$ compared with the Gm cultivar. It can be concluded from the study done that there were differences in TNC between cultivars, however, the TNC content in Gk cultivar was not different with Gt cultivar, while Gm cultivar have the lowest $(P<0.01) T N C$ content. At reproductive phase all cultivars have higher $(P<0.01)$ TNC and starch content than at vegetative phase.

Napier grass (PennisetumPurpureumSchum) is a perennial grass, famous throughout the wet tropics because of its high production capability. Several cultivars have been developed and were introduced to Indonesia, Malaysia, Philippines and South East Asian Countries. Such as cultivars of Africa, Hawaii, Trinidad, Merkeri, King, Taiwan and Mott are closely related. There are differences between cultivars morphology, growth rate and response to farming practices that lead to differences in production and non-structural carbohydrate content.
\end{abstract}

Keywords: Sugar, Napier Grass, TNC, Starch. Milk Production

\section{Introduction}

Proper grazing management is the major factor determining yield and quality of forage.Proper grazing management includes keeping the grass vegetative-this means leaving enough residue $(6-8 \mathrm{~cm})$ after grazing to allow regrowth from photosynthesis in addition to root reserves. Grazing occurs before the reproductive stage $(8-16 \mathrm{~cm}$ depending on species) so quality is high and growth fast. Proper management also includes rest after grazing. Pastures need adequate time to replenish root reserves as more continuous grazing weakens pasture plants. Thus, cows should be offered fresh forage after each milking and not be allowed to regraze areas grazed less than 3 days prior.

Selection of forages also impacts both yield and quality. Grasses and legumes grown together typically increase $10 \%-15 \%$ compared to monocultures. Forage intake is also increased by adding legumes to pasture. The legumes, grasses, and pastures are better because of greater yields, better persistence, reduced bloat and higher milk production per acre. Cows on pasture tend to have lower grain intake which decreases total dry matter intake but does not consistently meet milk yields, body weight or cow condition. When milk per acre is calculated, the legume-grass pasture system can produce similar milk yield per acre compared to confinement feeding. Forage utilization in grazing dairy cows may differ from forage utilization in cows fed alfalfa silage. Ruminal disappearance of dry matter is faster and more extensive for cows on fresh forage diets than for cows on alfalfa silage diets. When fresh grass is compared to ensued grass, significant water soluble carbohydrates are lost.

Lower dry matter intakes, lower rumen volumes and lower digesta weights of cows on pasture relative to cows fed afalfa silage indicate something other than physical fill (NDF) limits intake. The rumen environment $(\mathrm{pH})$ of pastured cows, unlike cows fed alfalfa silage, is suggested to be more controlled by intake of forage thanby intake of grain. Cows on pasture can have the same level of milk production and milk components as 
cows fed alfalfa silage but they consume less grain and forage which leads to lower rates of forage and liquid passage, lower total digesta weight and lower rumen volume. Cows on pasture also have higher rumen $\mathrm{pH}$ ammonia concentrations and lower total VFA (Volatile Fatty Acid) concentrations. Supplemental grain iscritical if high milk output and maintenance of body condition are priorities. The benefits to grain supplementation on pasture include increased energy intake; stimulation of rumen bacterial protein synthesis and increased dry matter intake.

Milk yield, body condition and reproduction respond to supplemental grain. Grain supplementation will also make up for reductions in forage quality. Starch utilization, which assists rumen microbial protein synthesis is another benefit but is affected by amount, form and frequency of feeding. Finer grains can improve utilization due to rapid rumen passage.

Research with high producing dairy cattle indicates that cows under grazing conditions lose more body condition in early lactation and tend not to gain weight as rapidly in mid to late lactation compared to confinement cows. The single most important factor determining profitability in grazing, it is about intake.

From this study a relatively new analysis was used to evaluate grass forage quality has the measurement of (Total Non-Structural Carbohydrate of three cultivars of Napier grass (PennisetumPurpureum) TNC (Downing, 2007). Determination of NSC composition and content is required to estimate the resources available for plant growth and to evaluate the energy value of feed. (Zhao et al., 2010). TNC stored in various plant tissues varies according to species (Herbert, 1996) and cultivars (Shewmakeret al., 2006). Higher level of NSC may be found in very mature forage (Watts, 2008). The content of storage carbohydrate in plants are always changing, the content tends to rise in the morning, reaching a maximum in the afternoon and decrease at night (Longlandet al., 1999).

NSC is a source of energy available for rumen microbes (Sophie et al., 2010). High sugar content in grass allows more efficient utilization of nitrogen in the rumen, preventing excess from being excreted that will cause environmental pollution (Miller et al., 2001; Lovett et al., 2004). Increase non-structural carbohydrates content are fermented to give some energy to support $\mathrm{N}$ conversion into microbial protein (Hutington and Burns, 2007).

The use of the principles and objectives of efficient grazing management is the management practices that to produce plants that persistent, high quality of production, and to maintain sufficient leaf area and the level of NSC to store energy (Smith and Lacefield, 2009). Implementation of these strategies has the potential to maintain the stability of grassland ecosystem and enable sustainable livestock production (Manske, 1999).

Studies on the determination of NSC, such as total sugar and starch in vegetative and reproductive growth in different cultivars of napier grass is still very limited. Therefore, the research to determine TNC of three cultivars of napier grass at vegetative and reproductive phase have to be done. The objectives of the studies were to determine TNC of three cultivars of napier grass at vegetative and reproductive phases. Similar research can be applied on other plant species and grasses and forages to raise livestock's especially in the dairy production.

\section{Literature Review}

Research from several counties has demonstrated that with well-managed grazing systems, pasture intakes of 35 to $40 \mathrm{lb}(15.42 \mathrm{~kg}$ to $18.14 \mathrm{~kg})$. of dry matter (DM)/cow/day can be achieved by Holsteins with pasture as the only feedstuff. This is about $3 \%$ of the bodyweight for Holstein cows. In a study at Penn State University, a daily pasture intake of $45 \mathrm{lb} / \mathrm{DM} / \mathrm{cow}(20.41 \mathrm{~kg} / \mathrm{DM} / \mathrm{cow})$ with high genetic Holstein cows fed grass pasture as the only feedstuff. This intake can provide adequate energy to theoretically support up to 50 to $60 \mathrm{lb}$. of milk/day (22.67kg of milk to $27.22 \mathrm{~kg}$ of milk/day) with Holsteins. However, most cows may still lose substantial body condition to achieve this production since energy outgo exceeds energy intake. Pasture intake and milk yields of this magnitude may only be achieved in the spring or early summer when pasture growth and quality are high. With the generally favorable price of milk in relation to grain supplement in the USA and other countries, it is most economical for most graziers to feed supplemental concentrates and feedstuffs rather than feed only pasture

The chemical composition and digestibility of grass are affected more by stage of maturity than by other management factors, such as species, DM, or type of harvest system. The decline in digestibility of nutrients in first growth forage is approximately .55 to $.68 \% / \mathrm{d}$ and is dependent on the method of estimation. The decline in digestible DMI in first growth is .3 to $.5 \% / \mathrm{d}$. The use of silage additives has become an integral part of forage management, and improvements in DMI and milk production are documented. Particle size and type of harvest equipment significantly affect eating behavior and efficiency of milk production. Wilting of silage results in an increase in DMI and efficiency of microbial protein production.

It has been suggested that organic dairy farms might suffer from poor fertility due to a metabolic energy gap in early lactation (limit of maximum of $40 \%$ of DMI as concentrate and variable forage quality). With relatively low average herd yields in UK organic herds (Weller et al., 1996. 5125 litres/305 days; Hovi and 
Roderick, 1999. 5900 litres/305 days; DEFRA 2000, 2006. 5,900 litres/305 days; MDC, 2006. 6,400 litres/305 days), this is not likely to be a problem unless herds with high yielding cows convert to organic production. Infertility, mastitis and lameness are major causes of culling (Esslemont and Kossaibati, 1997; Whitaker (2000) and hence important factors in the declining longevity of the dairy cow. Norgaard(1999) conclude that a higher level of physiological stress due to higher milk yield and concentrate consumption has led to increased mortality in dairy cows.

Selective breeding for increased milk yield is the root cause of declining longevity and unacceptably high levels of lameness, mastitis and metabolic diseases. New breeding goals are needed as a matter of urgency to produce more robust cows with improved health, welfare, fertility and longevity. Rauw (1989) comment that the fundamental solution is "to redefine the breeding goal in a broader perspective", which means "breeding animals with a long economical (re)productive life at a production level that is economical (i.e. production in relation to veterinary costs, etc.) without giving any signs of disturbed welfare".

According to Oltenacu and Algers (2005), the economic future of the dairy industry is related directly to public acceptance of its breeding and production practices. It is important to the dairy industry that welfare problems should be addressed before there is widespread condemnation of breeding and management practices. A new breeding goal aimed at improving fitness and tolerance of metabolic stress is necessary to prevent the decrease in the quality of life of dairy cows and instead, perhaps, enhance it."

The quantity of available pasture, which includes pasture height and density, is key to optimize milk production and profitability. We need to provide cows with pastures that allow them to consume high pasture intake. We need a pasture sward that provides a mouthful of highly digestible forage in every bite. If the pasture sward is too short, cows will not have as much intake per bite, and they will spend energy and grazing time. If animals are forced to graze pasture below 2 to 3 inches $(5.08 \mathrm{~cm}$ to $7.62 \mathrm{~cm})$, to a short stubble or residual height, this will likely reduce the pasture regrowth.

Owens (1959) reported that animals feeding on large amounts of WBG were susceptible to ruminal acidosis. Moreover, Kwatra et al. (1983) reported lactic acidosis in buffaloes consuming WBG diets, presenting with clinical signs such ataxia, dehydration, glazed eyes and diarrhea. Furthermore, Morel and Lehmann (1997) found latent ruminal acidosis in feedlot steers fed WBG (Weight Body Gain). In addition, Okwee-Acai and Acon (2005), reported increased incidence of lameness when dairy cows were fed with WBG diets compared to non-WBG diets (47.8 vs. $24.0 \%)$. It seems that ruminants fed large amounts of WBG have fast ruminal fermentation rates and low $\mathrm{pH}$ (3.8-4.8) due to low particle size and high soluble carbohydrates (Gierus et al. (2005). Therefore, when feeding animals on WBG proper concentrate and mix ration should be considered to avoid clinical signs and more DM intake from forages and leguminous grasses has to be encouraged.

\section{Plant Culture}

\section{Materials And Methods}

According to a study conducted by Budimanet al. (2011) three cultivar of napier grass were planted on 192 pots $(18 \times 35 \mathrm{~cm}$ with diameter $22 \mathrm{~cm})$, filled with regosol soils and were planted with three different napier grass cultivars, in which each cultivar required 64 vegetative planting materials. The study conducted consisted of three factors of cultivars $\mathrm{G}$ ) and two factors of growth (P). Cultivar factor of consisted Taiwan cultivar (Gt), King cultivar (Gk) and Mott cultivar (Gm). Meanwhile growth factor consisted of vegetative phase (P1) and reproductive phase (P2). Growth phase (P) nested within cultivar factor (G). Each treatment consisted of four replicates, therefore 192 pots were required. The pots then we divided according to the cultivar into 3 groups and each groups were divided into 8 plots. Each plots containing of 8 pots.

Pots were placed randomly following nested design (Steel and Torrie, 1980) in the pattern of randomization. The distance between each cultivar plots was $60 \mathrm{~cm}$, and between plots P1 and P2 was 30 $\mathrm{cm}$. Vegetative planting materials (cuttings), napier grass cultivars (Gt, Gk and $\mathrm{Gm}$ ) were planted in the pots using 3 cutting per pot. Thinning were done after 7 days of growth leaving one of the best plant in each pot. Urea fertilizer $(46 \% \mathrm{~N})$, phosphorus $(18 \% \mathrm{P} 205)$ and $\mathrm{KCI}\left(50 \% \mathrm{~K}_{2} \mathrm{O}\right)$ were given at 3 days-3 after thinning at the rate of $100 \mathrm{~kg}$ urea/ha and $50 \mathrm{kgTSP} / \mathrm{ha}$ and $50 \mathrm{KCI} / \mathrm{ha}$ or equivalent to $(0.52 \mathrm{~g} \mathrm{~N} /$ pot, $1.33 \mathrm{~g} \mathrm{P}$. O5/pot and $0.48 \mathrm{~g} \mathrm{~K}_{2} \mathrm{O} /$ pot. Watering and weeding were done if necessary.

\section{Data Collection}

Data of production was obtained at 8 week after planting (8WAP) for the treatment of vegetative phase and 13 weeks after planting (13WAP) for treatment reproductive phase. Plants were harvested at $10 \mathrm{~cm}$ above the soil surface then were weighed to determine the fresh weight. Chopped fresh samples were then oven dried at $55^{\circ} \mathrm{C}$ for 3 days. Dried samples then were $1 \mathrm{~mm}$ grounded by Wiley mill. These samples were used to determine the dry matter (AOAC, 2005), total sugars by Nelson-Somogi method (Apriyatonoet al., 1989) and starch content by acid hydrolysis. The TNC or NSC were calculated by Longland and Byrd (2006) with the formular: $\mathrm{NSC}=\mathrm{TNC}=\mathrm{Starch}(\%)+\operatorname{Sugar}(\%)$. 


\section{Data Analysis}

The effects of cultivars and growth phase were determined by analysis of variance (ANOVA) according to Steel and Torrie (1980). The differences between treatment means were determined using Dincan's Multiple Range Test.

\section{Total Sugar}

\section{Results And Discussion}

The results showed that there were differences in sugar content between cultivars of napier grass (Table 1). The highest $(\mathrm{P}<0.05)$ sugar content was found in Gt cultivar, followed by Gk cultivar $(\mathrm{P}<0.05)$ and the lowest $(\mathrm{P}<0.01)$ was in GM cultivar. The lowest of sugar content GM cultivar because it was used as source of energy for tillering (Bartholomew, 1999) and also for respiration and maintenance (Briske and Richard, 1994); and (Olson and Lacey, 1996). In accordance with the findings of Moran (2005) and Kozloskiet al. 2003), that napier grass cultivars Gm (54 tillers/plot) has puppies over cultivarsGt (26 tillers/plot and Gk (20 tillers/plot). Taset al. (2006) reported that there were differences in water soluable carbohydrate (WSC) content of four perennial ryegrass. Wadiet al. (2004) found that the total sugar content (TSC) of napier grass, King grass and hybrid napier grass were $11.6 \%, 13.4 \%$ and $16.6 \%$ respectively.

Table 1. Average Total Sugar, Starch and TNC in Cultivars Taiwan, King and Mott at Vegetative and Reproductive Phases

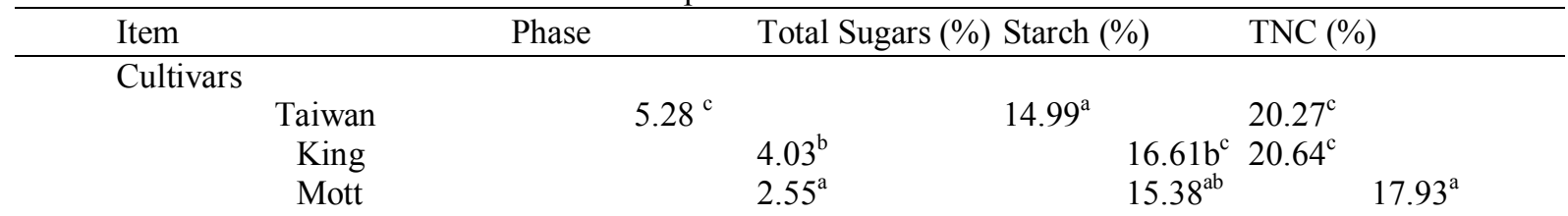

Growth Phase

Taiwan

\begin{tabular}{lllll} 
& Vegetative & $2.64^{\mathrm{a}}$ & $14.65^{\mathrm{a}}$ & $17.29^{\mathrm{a}}$ \\
\multirow{3}{*}{ King } & Reproductive & $7.2^{\mathrm{c}}$ & $15.32^{\mathrm{a}}$ & $23.24^{\mathrm{c}}$ \\
& & & & \\
\multirow{3}{*}{ Mott } & Vegetative & $1.72^{\mathrm{a}}$ & $15.89^{\mathrm{a}}$ & $17.61^{\mathrm{a}}$ \\
& Reproductive & $6.34^{\mathrm{c}}$ & $17.34^{\mathrm{c}}$ & $23.68^{\mathrm{c}}$ \\
& & & & \\
& & & $40.02^{\mathrm{a}}$ & $15.77^{\mathrm{a}}$ \\
& Vegetative & $1.75^{\mathrm{a}}$ & $16.73^{\mathrm{c}}$ & $20.09^{\mathrm{c}}$
\end{tabular}

Superscript (a.b), (b.c) by column cultivars and growth phase significantly different at $(\mathrm{P}<0.05)$ and (a.c) were significantly different at $(\mathrm{P}<0.01)$.

Total sugar at reproduction phase harvested at 13 weeks after planting were significantly (13 WAP) were significantly higher $(\mathrm{P}<0.01)$ compared to the vegetative phase harvested at 8 weeks $(8 \mathrm{WAP})$ for all cultivars tested. The high levels of sugar in the reproduction phase, could be caused by decreasing growth rate, so energy used reduced, but photosynthesis and sugars production still accured in the sugar accumulation. According to Watts (2008) the accumulation of sugars occurs when growth is slowly such that the products of photosynthesis exceed demand for growth. Starch is the main product of tropical grass phtosynethesis, and deposited in the chloroplast. Starch reserve in the chloroplast is mobilized and utilized by plant in the darkness at times of limited photosynthesis (Foyer, 1984). Wadiet al. 2004 found that the starch content of napier grass, King grass and hybrid napier grass were $3.12 \%, 3,58 \%$ and $5.67 \%$ respectively.

\section{Starch}

The results showed that there were differences in starch content among cultivars of napier grass. The highest $(\mathrm{P}<0.01)$ starch content was found in Gk cultivar, followed by Gm cultivar $(\mathrm{P}>0.05)$ and the lowest $(\mathrm{P}<0.01)$ was in Gt cultivar (Table 1). The higher content of starch in Gk cultivar caused photo synthesis exceeds respiration activity.

Starch content in the reproductive phase at 13 WAP were significantly higher $(\mathrm{P}<0.01)$ than that at 8 WAP but not for Gt cultivar. The increase in starch content at in the reproductive phase can be attributed to the exceeding photosynthesis partly only used for respiration. Maturity is the main factor affected TSC content of forage, but environmental conditions may override stage of growth producing very mature forage with high NSC concentration (Watts, 2008). That phenomenon showed that the starch content increasing maturity of the 
plant. According to Chatterton et al. (2006), the starch content in vegetative tissues (up to $10 \% \mathrm{DM}$ ) generally increased with increasing maturity.

\section{Total Non-Structural Carbohydrates (TNC)}

TNC in the tropical grass composed of the total sugar and starch. The average TNC of napier grass Gt, Gk and Gm cultivar on vegetative and reproductive phase are presented in Table 1. The results showed that there were differences $(\mathrm{P}<0.01)$ in TNC content between cultivars of napier grass. The highest $(\mathrm{P}<0.01) \mathrm{TNC}$ was found inGk cultivar, followed by Gt cultivar $(\mathrm{P}>0.5)$ and the lowest $(\mathrm{P}<0.1)$ was in Gt cultivar. Wadiet al. (2004) found that TNC content of napier, King grass and hybrid grass $22.0 \%, 15.2 \%$ and $22.3 \%$ respectively.

$\mathrm{TNC}$ in the reproductive phase harvested at $13 \mathrm{WAP}$ were significantly higher $(\mathrm{P}<0.01)$ than $8 \mathrm{WAP}$ for all cultivars tested. The higher content of TNC in the reproductive phase was attributed to the increase of total sugar and starch in all cultivars due to increase in maturity. The results of this particular study conducted is in agreement with the report of Kozloskiet al. (2005) that NSC content in napier grass cultivars increased with increasing of age. A Motts cut 30, 50, 70, 90 days yields $108 \mathrm{~g} / \mathrm{kg} \mathrm{DM}, 117 \mathrm{~g} / \mathrm{kg} \mathrm{DM}, 144 \mathrm{~g} / \mathrm{kg}$ DM, respectively. Study conducted by Villanueva Avalos (2008) found that levels of TNC in WWB.Dahl grass 0.26 $\mathrm{g} / \mathrm{plant}$ in the vegetative phase was increased to $2.22 \mathrm{~g} / \mathrm{plant}$ at reproductive phase.

\section{Conclusion}

It can be concluded that there were differences in TNC content between cultivars of napier grass, however, the TNC content in Gk cultivar was not different with Gt cultivars, while Mott cultivar have the lowest TNC content. The reproductive phases showed that all cultivars higher TNC and starch content than at vegetative phase.

Therefore, the management of dairy cowsand pasture is a major challenge, given the variation in grass growth and grazing conditions during the grazing season. Allocation of the correct amount of area and pasture to achieve maximum intake is an important decision that the manager must make each day.

High yielding cows have a stronger hunger drive than low yielding cows, and consequently graze for longer times (500 to 700 minutes/day) and have high biting rates (up to 65 bites/minute). However, the major factor influencing pasture intake is the amount of herbage intake per bite, or bite mass. Bite mass can be controlled by management. Small increases in the intake/bite can have a major effect on daily pasture intake and animal performance. Bite size is primarily influenced by sward factors such as grass height and density of pasture, and the proportion of green leaf in the sward. If intake per bite declines, as it inevitably does on short swards, the behavioral constraints on biting rate and grazing time mean a reduction in daily forage intake. The amount of time spent grazing increases as the amount of pasture decreases, which is why high producing cows need to be provided a dense sward with at least 6 to 8 inches $(15.24 \mathrm{~cm}$ to $20.32 \mathrm{~cm})$ pasture height depending on the type of grass.

The inches $(\mathrm{cm})$ of available pasture is determined by measuring the height of the pasture and subtracting the desired stubble (residual) height. Pasture should be measured in several representative spots to get an average height. The total forage from the soil surface is 7 to 8 inches $(17.8 \mathrm{~cm}$ to $20.32 \mathrm{~cm})$ With a residual stubble height of 2 to 3 inches $(5.08 \mathrm{~cm}$ to $7.62 \mathrm{~cm})$, the cow has 4 to 6 inches $(10.16 \mathrm{~cm}$ to $15.24 \mathrm{~cm})$ of available forage. It is important that the stubble height be maintained to assure the survival of the desired plant species. This is especially so under drought conditions where over-grazing will severely damage stands and delay regrowth. Under severe drought conditions animals should be removed from pasture and fed stored forages.

\section{Acknowledgement}

The author of the article would like to thank the Researchers for dedicating their time and effort forpublishing the research article on the J. Indonesian Trop. Anim. Agric. 36 (2) June 2011 Titled: Total Nonstructural Carbohydrate (TNC) of Three Cultivars of Napier Grass (PennisetumPurpureum) at Vegetative and Reproductive Growth. and with the help of Directorate General of Higher Education, Ministry of National Doctoral Dissertion Grant Program Letter of Agreement in Accordance with the Implementation of Research Dissertions No: 481/SP2H/PP/DP2M/VI/2010, dated June 11, 2010.

\section{References}

[1]. AOAC. 2005. Official Methods of Analysis Association (18th. Ed.), Official Analytical Chemist. Association of Official Analytical Chemist, Washington, DC.

[2]. Apriyantono, A., D. Fardiaz., N.L. Puspitasari, Sedarnawati and S. Budiono. 1989. Analisis Pangan. PAU Pangan dan Gizi-IPB. Institut Pertanian Bogor.

[3]. Bartholomew, P. E. 1999. Growth of the grass plant. Agricultural production guidelines. Coordinated Extension veld in kwazulunatal, Veld 7.2. 
[4]. Briske, D. D. and J. H. Richards. 1994. Physiological responses of the individual plants to grazing: Current statues and ecological significance. In: Ecological implications of livestock herbivory in the west. (Eds. M. Vavra, W. A. Laycock, and R. D. Pieper). Soc. For Range Manage. Denver, Co.

[5]. Chatterton, N. J., K. A. Watts, K. B. Jensen, P. A. Harrison, and W. H. Horton. 2006. Nonstructural carbohydrates in oat forage. J. Nutr. 136:2113S.

[6]. DEFRA (2000) Organic dairy cows: milk yield and lactation characteristics in thirteen established herds and development of a herd simulation model for organic milk production. Project Report OF0170

[7]. DEFRA (2006) The development of organic milk production systems. Project Report OF0317.

[8]. Downing, T. 2007. Nonstructural Carbohydrates in Cool-season Grasses. Oregon State University Extension Service. Special Report 1079-E.

[9]. Gierus, M., L. de Jonge and G. A. L. Meijer. 2005. Physicochemical characteristics and degradation rate of soluble protein ob tained from the washout fraction of feeds. Livest. Produc. Sci. 97:219-225.

[10]. Herbert, S. J. 1996. Forage Harvest Management Legume. Department of Plant and Soil Sciences. University of Massachu setts Amherst. Crops, Dairy, Livestock News. Vol. 1:2.

[11]. Hovi, M. and Roderick, S. An investigation of the incidence, treatment strategies and financial implications of mastitis in organic and conventionally managed UK dairy herds. An attachment to a Scientific Report to MAFF, 1999.

[12]. Hutington, G. B. and J. C. Burns. 2007. Afternoon harvest increases readily fermentable carbohydrate concentration and voluntary intake of gamagrass and switchgrass baleage by beef steers. J Anim Sci. 85:276-284.

[13]. Kozloski, G. V., and J. Perottoni, M. L. S. Ciocca, J. B. T. Rocha, A. G. Raiser, and L. M. B. Sanchez. 2003. Potential nutritional assessment of dwarf elephant grass (Pennisetum purpureum Schum. Mott) by chemical composition, digestion and net flux of oxygen in cattle. Anim. Feed Sci. Technol. 104:29-40.

[14]. Kozloski, G. V., and J. Perottoni and L. M. B. Sanchez. 2003. Influence of regrowth age on the nutritive value of dwarf elephant grass hay (Pennisetum purpureum Schum. Cv. Mott) by chemical composition, digestion and net flux of oxygen in cattle. Anim. Feed Sci. Technol. 119:1-11.

[15]. Kwatra, M. S., S. Nem Singh and M. S. Oberoi. 1983. Spontaneous brewer's grain toxicity in buffaloes. Indian J. Anim. Sci. 53:330-331.

[16]. Longland A. C., A. J. Cairns and M.O. Humphreys. 1999. Seasonal and diurnal changes in fruction concentration in Lolium perenne: implications for the grazing management of equine predisposed to laminitis. Proceedings, The 16th Equine Nutrition and Physiology Society. Raleigh NC, June 2-5, 1999, Page 258-259.

[17]. Longland A. C. and B. M. Byrd. 2006. Pasture nonstructural carbohydrates and equine laminitis. J. Nutr. 136:2099S-2102S.

[18]. Lovett, D. K., A. P. Bortolozzo, P. Conaghan, P. O'Kelly and F.P O'Mara. 2004. In vitro total and methane gas production as influenced by rate of nitrogen application, season of harvest and perennial ryegrass cultivar. Grass Forage Sci. 59:227-232.

[19]. Manske, L. L., 1999. Defoliation applied at some phonological growth stages negatively affects grass plants. NSDU Dickinson Research Extension Centre. Summary Range Management Report DREC 99-3013. Dickinson, ND.

[20]. Miller, L. A., J. M. Moorby, D. R. Davies, M. O. Humpherys, N. D. Schollan J.C. MacRae and M.K. Theodorou. 2001. Increased concentration of water-soluable carbohydrate in perennial ryegrass (Lolium perenne L.) Milk production from late-lactation dairy cows. Grass and Forage Sci. 56:383-394.

[21]. Morel, I. ; Lehmann, E., 1997. Brewer's grains silage in cattle fattening. Agrarforsc., 4 (3): 111-114

[22]. Murdock, F. R., A. S. Hodgson and R. E. Riley. 1981. Nutritive value of wet brewers' grains for lactating dairy cows. J. Dairy Sci. 64:1826-1832.

[23]. Norgaard, N. H., Lind, K. M. and Agger, J. F. (1999) Cointegration analysis used in a study of dairy-cow mortality. Preventive Veterinary Medicine,42: 99-119.

[24]. Olson, E. and J. R. Lacey. 1996. Basic principles of grass growth and management. EB-35. Extension Service. Montana State University.

[25]. Oltenacu, P. A. and Algers, B. (2005) Selection for increased production and the welfare of dairy cows: are new breeding goals needed? Ambio, 34: 311-315.

[26]. Owens, E. L. 1959. Observations on the toxicity of brewers' grain for dairy cows. N.Z. Vet. J. 7:43-46.

[27]. Rauw, W. M., Kanis, E., Noordhuizen-Stassen, E. N. And Grommers, F. J. (1998) Undesirable side effects of selection for high production efficiency in farm animals: a review. Livestock Production Science, 56: 15-33

[28]. Shewmaker, G. E., H. F. Mayland, C. A. Roberts, P. A. Harrison, N. J. Chatterton and D. A. Sleper. 2006. Daily carbohydrate accumulation in eight tall fescue cultivars, Grass and Forage Sci.61:413-421.

[29]. Sophie, P., F.T. Gaetan, B. Annick, B. Gilles, C. Yves and R. Michaud. 2010. Drying procedures affect non-structural carbohydrates and other nutritive value attributes in forage samples. Anim. Feed Sci. Technol. 157 (3):139-150.

[30]. Steel, R. G. D. and J. H. Torrie. 1980. Principles and Procedures of Statistic. McGraw-Hill Book Co. Inc. New York.

[31]. Tas, B. M., Taweel, H. Z., Smit, H. J., Elgersma, A., Dijkstra, J. and S. Tamminga. 2006. Effects of perennial ryegrass cultivars on milk yield and nitrogen utilization in grazing dairy cows. J. Dairy Sci. 89:3494-3500.

[32]. Villanueva-Avalos, J. F. 2008. Effect of defoliation patterns and developmental morphology of forage productivity and carbohydrate reserves in WW-B. Dahl grass (Bothriochloa bladhii (RETZ) S.T. Blake. Phd Thesis. Range Science. Texas Tech. University.

[33]. Wadi, A., Y. Ishii and S. Idota. 2004. Effects cutting interval and cutting height on dry matter yield and overwintering ability at the established year in Pennisetum species. Plant Prod. Sci. 7 (1):88-96.

[34]. Watts, K. A., 2008. Carbohydrates in forages: what is a safe grass?. Proceedings, Kentucky Equine Research, Advanced Management of Gastrointestinal and Metabolic Diseases, Lexington, KY. April, 2008. Page1 -11.

[35]. Weller, R. F., Cooper, A. and Padel, S. Animal production during conversion. In: Conversion to organic production. IGER Technical Review no. 4, 1996.

[36]. Zhao, D., Mackown, C.T., Starks, P. J. and B.K. Kindiger. 2010. Rapid analysis of nonstructural carbohydrate components in grass forage using microplate enzymatic assays. Crop Sci. 50:1537-1545. 